\title{
Posterior Reversible Encephalopathy Syndrome: A Case of Hypercalcemia
}

\author{
Síndrome de Encefalopatia Posterior Reversível: Um \\ Caso de Hipercalcemia
}

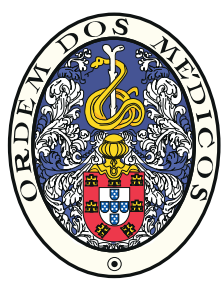

Ana PONCIANO $₫ 1$, Vera VIEIRA ${ }^{1}$, José LEITE ${ }^{1}$, Célio FERNANDES 1

Acta Med Port 2018 Jun;31(6):338-340 - https://doi.org/10.20344/amp.9714

ABSTRACT

Posterior reversible encephalopathy syndrome is an encephalopathy that can be clinically characterized by headache, altered mental status and/or seizures. Neuroimaging demonstrates usually reversible bilateral subcortical vasogenic occipital-parietal edema. Exact pathophysiology remains unclear but is commonly associated with hypertension, renal failure, sepsis and use of immunosuppressive therapy. Its development in the setting of severe hypercalcemia is extremely rare. The authors report a case of posterior reversible encephalopathy syndrome in a normotensive patient with severe hypercalcemia as the only identifiable cause.

Keywords: Hypercalcemia; Posterior Leukoencephalopathy Syndrome

\section{RESUMO}

A síndrome de encefalopatia posterior reversível corresponde a uma encefalopatia que pode caracterizar-se clinicamente por cefaleia, alteração do estado de consciência e/ou crises epiléticas. A neuroimagem geralmente revela edema vasogénico subcortical bilateral occipito-parietal reversível. A fisiopatologia permanece por esclarecer mas frequentemente associa-se a hipertensão, insuficiência renal, sépsis e uso de terapêutica imunossupressora. O seu desenvolvimento no contexto de hipercalcémia severa é extremamente raro. Os autores apresentam um caso de síndrome de encefalopatia posterior reversível numa doente normotensa com hipercalcemia severa como etiologia mais provável.

Palavras-chave: Hipercalcemia; Síndrome da Leucoencefalopatia Posterior

\section{INTRODUCTION}

Posterior reversible encephalopathy syndrome (PRES) is a clinical neuroradiologic condition that can be characterized by headache, visual disturbances, seizures or altered consciousness presenting with imaging evidence of vasogenic edema. ${ }^{1}$ Both clinical and imaging characteristics are usually reversible..$^{2-3}$ In 1996, Hichey et al first described this syndrome and since then numerous case reports have been published..$^{4-7}$ Although the exact pathophysiology is not known, PRES has been linked to arterial autoregulatory dysfunction and vascular injury. The number of associated conditions with PRES has increased although hypertension remains the most common, as well as renal disease, sepsis and immunosuppressive drug use. ${ }^{8}$ Hypercalcemia is an extremely rare cause of PRES. ${ }^{9}$ We report the case of PRES associated with a hypercalcemic crisis.

\section{CLINICAL CASE}

A67-year-old female was brought to the emergency room after experiencing one week of band-like occipital headache, polyuria, fatigue and three days of progressive mental status changes. She had undergone total thyroidectomy in 1997 due to bilateral, benign, multinodular goiter with postsurgical hypoparathyroidism. Despite hypercholesterolemia, the patient was otherwise healthy. One month ago, she was admitted for hypocalcemic tetany and doubled her oral calcium intake to $4000 \mathrm{mg}$ daily. On physical examination, the patient was afebrile; blood pressure was $135 / 86 \mathrm{mmHg}$, heart rate $88 \mathrm{bpm}$. She remained normotensive during

hospitalization. Her neurologic examination revealed decreased alertness, temporo-spatial disorientation, loss of recent and remote memory, generalized hypotonia and diffuse hyporreflexia. There were no sensory deficits. Her clinical status was aggravated. A generalized tonic-clonic seizure occurred and the patient became stuporous. She started anticonvulsant therapy with levetiracetam $500 \mathrm{mg}$ IV bid but her mental status continued to deteriorate. Head computed tomography (CT) was unremarkable. Routine laboratory tests revealed serum creatinine of $0.81 \mathrm{mg} / \mathrm{dL}$, with fractional excretion of sodium of $2.9 \%$ and a calculated glomerular filtration rate of $40 \mathrm{~mL} / \mathrm{min}$. It also disclosed a marked hypercalcemia with serum calcium level of 4.55 $\mathrm{mmol} / \mathrm{L}(18.2 \mathrm{mg} / \mathrm{dL})$, corrected with an albumin level of $38 \mathrm{~g} / \mathrm{L}$ to $5.2 \mathrm{mmol} / \mathrm{L}$ (20.8 $\mathrm{mg} / \mathrm{dL})$; hypomagnesemia (0.48 $\mathrm{mmol} / \mathrm{L})$ and serum phosphorus within normal range (1.34 $\mathrm{mmol} / \mathrm{L}$ ). Thyroid-stimulating hormone (TSH) was $0.46 \mu \mathrm{Ul} /$ $\mathrm{mL}$ with low serum parathyroid hormone (PTH) of $0.5 \mathrm{pg} /$ $\mathrm{mL}$. Cerebrospinal fluid analysis revealed mild lymphocytic pleocytosis and normal protein levels, which was attributed to the seizure. The electrocardiogram showed sinus rhythm, heart rate of $83 \mathrm{bpm}$, with short QT interval (QT/QTc: 253/331 ms) (Fig. 1). Electroencephalogram depicted generalized slowing with no evidence of seizure activity. A brain magnetic resonance imaging (MRI) was performed revealing cortical and subcortical occipital symmetric hyperintensity on FLAIR-weighted images (Fig. 2A). The patient was treated with fluid loading and forced

1. Serviço de Medicina 2. Centro Hospitalar de Leria. Leiria. Portugal.

$\triangle$ Autor correspondente: Ana Ponciano. anaponciano@sapo.pt

Recebido: 21 de setembro de 2017 - Aceite: 27 de fevereiro de 2018 | Copyright @ Ordem dos Médicos 2018 


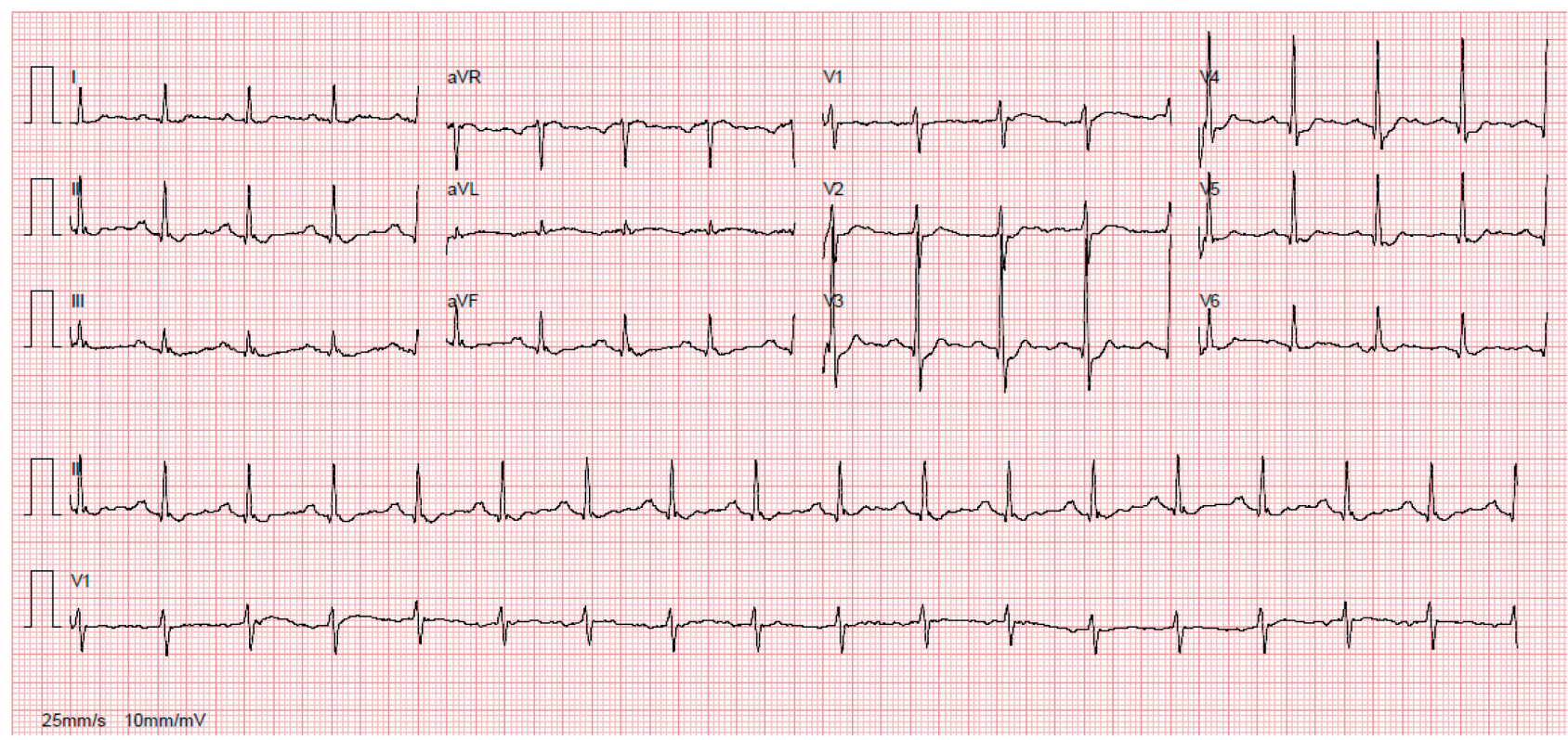

Figure 1 - Electrocardiography showing short QT interval due to hypercalcemia
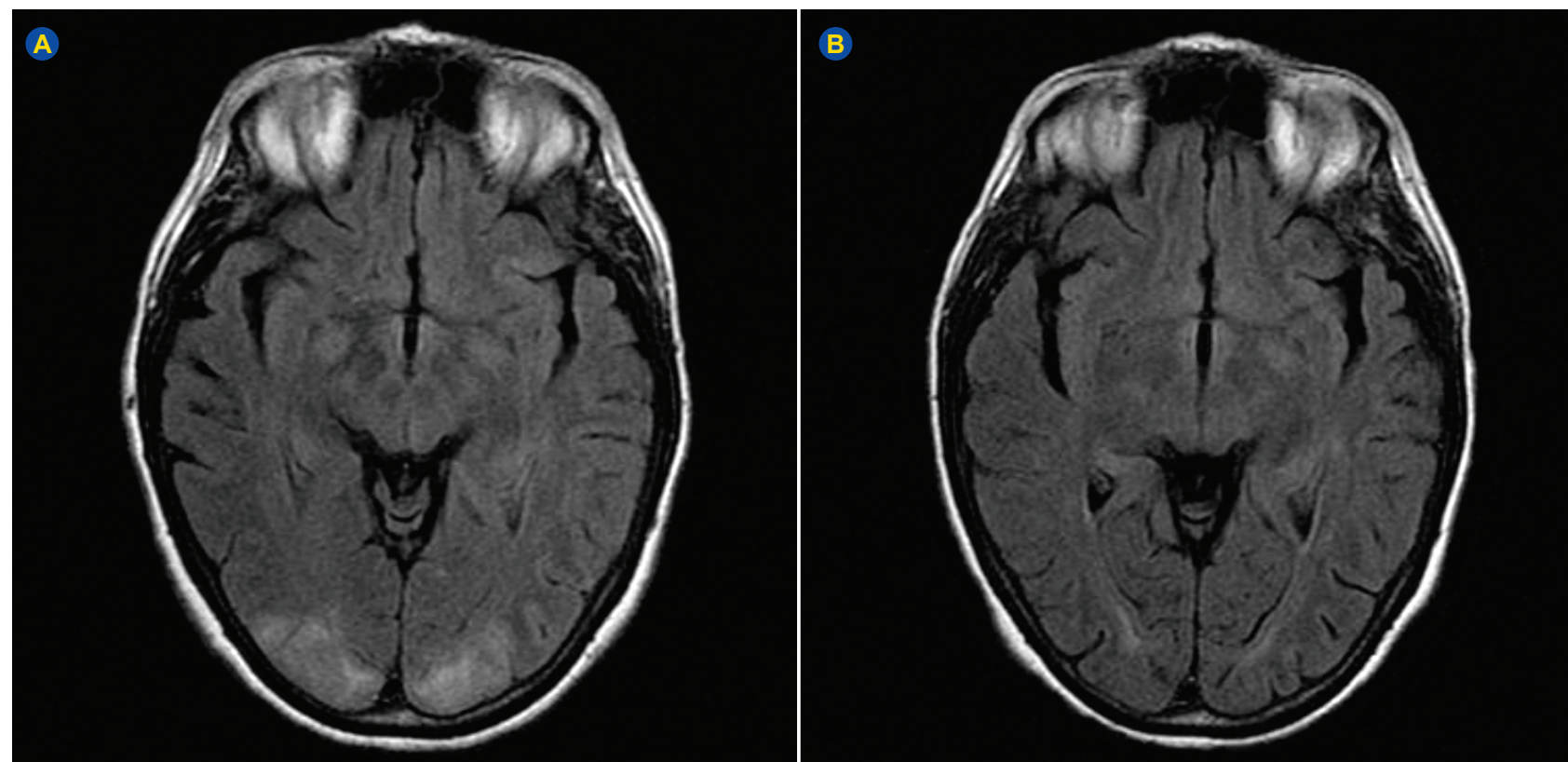

Figure 2 - Brain MRI: axial FLAIR-weighted imaging: (A) showing bilateral cortical and subcortical occipital hyperintensity. (B) 15 days later, MRI revealing complete remission of occipital signal abnormalities

diuresis. Within the next few days the calcium serum level normalized and the patient's mental and clinical status slowly improved. Routine laboratory values showed serum calcium level of $2.28 \mathrm{mmol} / \mathrm{L}(9.12 \mathrm{mg} / \mathrm{dL})$, corrected with an albumin of $39 \mathrm{~g} / \mathrm{L}$ to $2.30 \mathrm{mmol} / \mathrm{L}(9.2 \mathrm{mg} / \mathrm{dL})$, serum magnesium of $0.81 \mathrm{mmol} / \mathrm{L}$, and serum phosphorus of $1.46 \mathrm{mmol} / \mathrm{L}$. Subsequent brain MRI showed that the brain lesions had disappeared, suggestive of PRES (Fig. 2B). On clinical examination, her neurological symptoms had resolved and the patient, asymptomatic, was discharged with advice to increase oral fluid intake to $2 \mathrm{~L}$ per day and daily dose of levothyroxin $0.1 \mathrm{mg}$, calcium $1800 \mathrm{mg}, 1.25$ - dihidroxicholecalciferol $0.25 \mu \mathrm{g}$, magnesium $520 \mathrm{mg}$ and colecalciferol $520 \mathrm{mg}$ monthly.

\section{DISCUSSION}

PRES is an encephalopathy characterized by numerous neurological symptoms, including headache and visual disturbances. Typically, the clinical diagnosis is supported by MRI findings with vasogenic edema on T2 and FLAIR sequences. ${ }^{7}$ The posterior brain regions are predominantly affected due to their susceptibility to hyperperfusion. ${ }^{5}$

The syndrome appears to affect patients in all age groups, with a female predominance. Studies have attempted to estimate the incidence of PRES but it remains unknown. ${ }^{5}$

Besides hypertension, various risk factors have been implied such as sepsis, renal failure and exposure to immunosuppressants. However, the occurrence of PRES 
associated with hypercalcemia is extremely rare. ${ }^{6}$ To date, only a few cases have been previously reported and several of them were also associated with hypertension, hence isolated hypercalcemia could not account for the development of PRES.

Mild hypercalcemia is usually well tolerated but higher or rapid elevation in serum calcium levels can lead to organ dysfunction, including cardiovascular and central nervous system. ${ }^{8,10,11}$ Neurologic manifestations are mainly cognitive and neuromuscular in nature and range from personality changes, to lack of concentration, memory impairment, and, in severe cases, lethargy and coma. ${ }^{12}$ Other rarely reported neurologic manifestations include PRES. ${ }^{7,8}$

The most common cause of hypercalcemia is primary hyperparathyroidism either due to parathyroid adenoma, or due to malignancies, granulomatous diseases and iatrogenic causes. ${ }^{12}$ Therefore, the diagnosis of PRES in the setting of hypercalcemia requires a high level of suspicion.

Within our case, the patient had postsurgical hypoparathyroidism and hypercalcemia that we considered as the PRES induced cause. The overall work-up was unremarkable except for severe hypercalcemia.

Postsurgical hypoparathyroidism results from inadvertent removal or devascularization of parathyroid glands during thyroid and parathyroid surgery and is the most common cause of acquired permanent hypoparathyroidism. It usually presents as hypocalcemia and hyperphosphatemia or high-normal serum phosphorus. Calcium supplements and vitamin $D$ analogues effectively treat associated hypocalcemia. ${ }^{13}$

In our case, the patient was taking $4000 \mathrm{mg}$ of oral calcium daily due to hypocalcemic tetany hence hypercalcemia at presentation, as a result of excessive oral intake of calcium supplement and concomitant dehydration. The symptoms improved with complete resolution following normalization

\section{REFERENCES}

1. Fisher M, Schmutzhard E. Posterior reversible encephalopathy syndrome. J Neurol. 2017;264:1608-16.

2. Bartynski WS. Posterior reversible encephalopathy syndrome,part 1: fundamental imaging and clinical features. Am J Neuroradiol. 2008;29:1036-42.

3. Rykken JB, McKinney AM. Posterior reversible encephalopathy syndrome. Semin Ultrasound CT MR. 2014;35:118.

4. Hinchey J, Chaves C, Appignani B, Breen J, Pao L, Wang A, et al. A reversible posterior leukoencephalopathy syndrome. $\mathrm{N}$ Engl J Med. 1996;334:494-500.

5. Fugate JE, Rabinstein AA. Posterior reversible encephalopathy syndrome: clinical and radiological manifestations, pathophysiology, and outstanding questions. Lancet Neurol. 2015;14:914-24.

6. Toledano M, Fugate JE. Posterior reversible encephalopathy in the intensive care unit. Handb Clin Neurol. 2017;141:467-83.

7. Kastrup O, Maschke M, Wanke I, Diner HC. Posterior reversible encephalopathy syndrome due to severe hypercalcemia. J Neurol. 2002;249:1563-6.

8. Camara-Lemarroy C, Gonzalez-Moreno EI, Ortiz-Corona JJ, Yeverino- of serum calcium level with great response to aggressive hydration and forced diuresis. As such, hypercalcemia was considered the only identifiable cause of PRES.

The mainstay of treatment is related towards the triggering factor. Antiepileptic therapy may be used for seizure control. The overall prognosis is favorable, with complete resolution of symptoms, but persistent sequelae may result in more severe cases. ${ }^{14}$

To conclude, PRES should be considered in patients with hypercalcemia and neurological symptoms associated with suggestive neuroimaging changes. Correction of underlying cause is paramount in treatment and it seems associated with an excellent prognosis.

\section{PROTECTION OF HUMANS AND ANIMALS}

The authors declare that the procedures were followed according to the regulations established by the Clinical Research and Ethics Committee and to the Helsinki Declaration of the World Medical Association.

\section{DATA CONFIDENTIALITY}

The authors declare having followed the protocols in use at their working center regarding patients' data publication.

\section{PATIENT CONSENT}

Obtained.

\section{CONFLICTS OF INTEREST}

All authors report no conflict of interest.

\section{FUNDING SOURCES}

This research received no specific grant from any funding agency in the public, commercial, or not-for-profit sectors.

Castro SG, Sanchez-Cardenas M, Nuñez-Aguirre S, et al. Posterior reversible encephalopathy syndrome due to malignant hypercalcemia:ph ysiopathological considerations. J Clin Endocrinol Metab. 2014;99:11126.

9. Fugate JE, Claassen DO, Cloft HJ, Kallmes DF, Kozak OS, Rabinstein $\mathrm{AA}$, et al. Posterior reversible encephalopathy syndrome: associated clinical and radiologic findings. Mayo Clin Proc. 2010;85:427-32.

10. Carroll R, Matfin G. Endocrine and metabolic emergencies: hypercalcemia. Ther Adv Endocrinol Metab. 2010;1:225-34.

11. Ahmad S, Kuraganti G, Steenkamp D. Hypercalcemic crisis: a clinical review. Am J Med. 2015;128: 239-45.

12. Agrawal L, Habib Z, Emanuele NV. Neurologic disorders of mineral metabolism and parathyroid disease. Handb Clin Neurol. 2014;120:73748.

13. Khan MI, Waguespack SG, Hu MI. Medical management of postsurgical hypoparathyroidism. Endocr Pract. 2011;17:18-25.

14. Feske SK. Posterior reversible encephalopathy syndrome: a review. Semin Neurol. 2011;31:202-15. 